\title{
Assessing the Effects of Solarization and Sodium Azide Amendments on Selected Soil Parameters, Enzyme Activities and Microbial Populations
}

\author{
Anthony S. Kumi ${ }^{1}$, Victor Khan ${ }^{2}$, Ramble O. Ankumah ${ }^{1}$ \\ ${ }^{1}$ Department of Agricultural and Environmental Sciences, Tuskegee University, Tuskegee, USA; ${ }^{2}$ George Washington Carver Agri- \\ culture Experiment Station, College of Agriculture, Environment and Nutrition Sciences, Tuskegee University, Tuskegee, USA. \\ Email: akumi@mytu.tuskegee.edu,vkhan@mytu.tuskegee.edu, rankum@mytu.tuskegee.edu
}

Received February $16^{\text {th }}, 2013$; revised March $26^{\text {th }}, 2013$; accepted April $5^{\text {th }}, 2013$

Copyright (C) 2013 Anthony S. Kumi et al. This is an open access article distributed under the Creative Commons Attribution License, which permits unrestricted use, distribution, and reproduction in any medium, provided the original work is properly cited.

\begin{abstract}
Soil borne pathogens result in serious losses in yield of crops grown in the United States (US) and various parts of the world. One of the most effective chemicals used to control these pathogens was methyl bromide $\left(\mathrm{CH}_{3} \mathrm{Br}, \mathrm{MeBr}\right)$, a pre-plant fumigant with a broad spectrum of activity. Sodium azide has been proposed in combination with solarization as a viable alternative to replace $\mathrm{MeBr}$ due to environmental concerns with respect to ozone depletion in the stratosphere and as a possible carcinogen. However, the possible impacts of sodium azide as a soil pollutant and its effect on soil biological processes have not been fully studied. In this study the effect of sodium azide used alone and in combination with solarization and mulching on selected soil enzyme activities (phosphomonoesterases, arylsulfatase and phosphodiesterase) were assessed. Responses of arylsulfatase and phosphodiesterase to solarization and mulching and azide treatment were found to be affected in the same way, suggesting a similar mode of action. Soil pH in control soils was significantly increased by azide application; however, in mulched soils, $\mathrm{pH}$ was decreased. The significant decrease in soil $\mathrm{pH}$ in mulched soils may be very important in explaining the increase in the acid phosphatase activity observed in mulched soils. Overall, solarization and sodium azide treatment significantly reduced both fungi and bacterial populations but the responses among the various treatments varied significantly.
\end{abstract}

Keywords: Sodium Azide; Solarization; Methyl Bromide; Soil Enzyme Activity; Microbial Populations

\section{Introduction}

Soil borne pathogens result in serious yield losses of nuts, fruits, and vegetables grown in the US and worldwide. One of the most effective chemicals used to control these pathogens was methyl bromide $\left(\mathrm{CH}_{3} \mathrm{Br}, \mathrm{MeBr}\right)$, a pre-plant fumigant with a broad spectrum of activity. $\mathrm{MeBr}$ and Chloropicrin (CP) were applied to soils to control persistent weeds, nematodes, and soil bornepathogens and were reliable and effective tools for controlling these soil-borne-pathogens. They were commonly used in strawberry (Fragaria ananassa) cultivation, and other high value fruits and vegetable crops. The heavy dependence on $\mathrm{MeBr}$ as a fumigant has caused serious environmental concerns such as the destruction of the ozone layer, thus allowing harmful radiation to enter the earth's atmosphere [1,2]. As a result of the risks associated with methyl bromide $\left(\mathrm{CH}_{3} \mathrm{Br}, \mathrm{MeBr}\right)$ in deplet- ing the ozone layer, 160 nations signed a treaty in 1993, known as Montreal protocol, under the sponsorship of the United Nations Environment Program (UNEP). Sodium azide as an amendment has been proposed in combination with solarization to ameliorate this problem.

Soil solarization is a non-chemical soil disinfestation method first developed for the control of soil borne pathogens in Israel and California during the 1970s and is an Integrated Pest Management (IPM) approach for the control of soil borne pathogens, pests and weeds [3]. It has attracted interest in many warm climate countries due to its effectiveness, simplicity, low cost, and safety to humans, plants, animals and the environment. Its mode of action involves complex mechanisms of physical, chemical, and biological control through a passive hydrothermal process, utilizing solar radiation [4].

The use of solarization on a commercial scale is limited primarily by two important factors: the long time 
required for the completion of the solarization process and the climatic conditions existing in the different geographical regions of the world. In California, West Texas, Israel, and the Middle East, where there is limited cloud cover, effective soil solarization is achieved in 30 days. However, in the Southeastern US, where there is extensive cloud cover during the hot summer months, 90 days are required to achieve similar results to those in California and the Middle East [5]. Therefore, there is a need in the Southern US to reduce the solarization period and achieve comparable results to those areas of the world where soil solarization lasts for 30 days.

Several research trials have been conducted to reduce solarization time by incorporating different amendments such as poultry litter and other materials during the solarization process $([6,7]$. Sodium azide, also known as Azium, Azide, Kazoe, Smite, and Hydrazoic acid (Na $\left(\mathrm{N}_{3}\right)$ ), was evaluated as an amendment with soil solarization as an alternative to methyl bromide with promising results [8]. One of the major advantages of soil solarization is that it causes microbial population shifts in the treated soil, and encourages the growth of microbial antagonists against soil pathogens [9]. However, when a chemical, such as sodium azide, is combined with soil solarization, not much is known about its biocidial activities on the different microbial populations in the soil, and also long-term effects on the soil quality. For example, sodium azide is a known microbial inhibitor and its effects on the indigenous microbial population have been rarely studied in connection with its use as an amendment with soil solarization practices. Solarization has also been known to cause microbial shifts in the soil but its ultimate impact on ecosystem sustainability has not been studied.

Therefore, the overall objective of this study was to examine the overall effects of sodium azide used as an amendment in combination with solarization and mulching on soil biological and chemical processes by evaluating its effects on soil microbial populations and selected enzyme activity.

The specific objectives of this study were to determine the effects of sodium azide used alone or in combination with solarization and mulching: 1) on soil $\mathrm{pH}$ and organic matter; 2) on selected soil enzyme activities (Acid and Alkaline phosphomonoesterases, Arylsulfatase and Phosphodiesterase); and 3) on soil microbial populations ("total" bacteria and fungi).

\section{Materials and Methods}

\subsection{Study Plots and Soil Sampling}

The study plots were located at the George Washington Carver Agricultural Experimental Station (GWCAES), Tuskegee University, Tuskegee, Alabama, located at latitude $30^{\circ} 27^{\prime} \mathrm{N}$ and longitude $85^{\circ} 42^{\prime} \mathrm{W}$, with an elevation of 144.72 feet above sea level. The soil type at the study site was characterized as Norfolk sandy loam (fine, siliceous, thermic, Typic Paleudults) with a $\mathrm{pH}$ of about 5.9 and organic matter content of less than $1 \%$.

Plots were ploughed, harrowed and beds were mechanically formed with the following dimensions of $20 \mathrm{ft}$ $\times 2 \mathrm{ft}(6.67 \mathrm{~m} \times 0.67 \mathrm{~m})$. They were then covered with either transparent low-density clear polyethylene or high-density white on black polyethylene agriplastic mulch or uncovered bare soil control. After the beds were mulched, drip irrigation tubes were placed on the beds. Sodium azide was applied at the rate of 1001 bs/acre using "chemigation" method, and the subplots were solarized for 15 or 30 days or were mulched with white on black plastic mulch. "King Arthur" bell pepper (Capsicum annum) transplants were transplanted on the plots after completion of the solarization period.

Triplicate soil samples from each plot were taken after crops reached senescence using a soil auger. The samples from each plot were composited and transported to the Water and Environmental Quality Laboratory at Tuskegee University and refrigerated at $4^{\circ} \mathrm{C}$ until analyzed. Soil enzyme activity and microbial populations' determination were performed using methods described below.

\subsection{Soil Enzyme Activity Assays}

Phosphomonoesterases (Acid and Alkaline) were determined using the method of Tabatabai and Bremner [10]. Soil samples used for enzyme activity assays were first air-dried. One gram of the air-dried soil was placed in a $50 \mathrm{~mL}$ Erlenmeyer flask and incubated in the respective phosphatase substrate in $4 \mathrm{~mL}$ of Modified Universal Buffer (MUB), at pH 6.5 or 11.0, respectively, for acid phosphatase and alkaline phosphomonoesterases determination. Para-nitrophenol released was extracted with $\mathrm{CaCl}_{2}$ and transmittance was determined using a spectrophotometer at $420 \mathrm{~nm}$. Phosphodiesterase and Arylsulfatase were determined similarly, using the methods described by Browman and Tabatabi [11] and Tabatabi and Bremner [12] respectively.

\subsection{Determination of Microbial Populations in Soil Samples}

"Total" bacterial and fungal populations were enumerated in the study plots using the modified plate dilution technique described by Curl and Rodriquez-Kabana [13]. Ten grams of soil were added to $90 \mathrm{~mL}$ of distilled water and stirred on a magnetic stirrer. One drop of the suspension was placed onto sterile Petri dishes $10 \mathrm{~cm}$ in diameter, with the desired media. For "total" fungi, potato dextrose agar (PDA) was added and mixed. For the "total" 
bacterial population enumeration, nutrient agar (NA) was used. Inoculated plates were inverted and incubated for 48 hours at $28 \pm 2{ }^{\circ} \mathrm{C}$ in the dark. After incubation, "total" fungal population was estimated from the number of colonies that exhibited mycelia growth on PDA. On nutrient agar (NA), "total" bacterial populations were enumerated.

\subsection{Determination of Soil Chemical Parameters}

The $\mathrm{pH}$ of the samples was determined as soon as they were brought from the field. Soil $\mathrm{pH}$ was determined for each sample by placing a $10 \mathrm{~g}$ subsample of air soil into a $120-\mathrm{mL}$ specimen cup and adding $20 \mathrm{~mL}$ of deionized water (1:2 soil:water). The soil-water suspension was swirled to mix the contents and allowed to stand for ten minutes to equilibrate. The $\mathrm{pH}$ was measured using a Fisher Accumet $\mathrm{pH}$ meter.

Organic carbon was determined using the wet oxidation method described by Walkely-Black [14] and modified by Peech et al. [15] and Grewelling and Peech [16] using air-dried soils that were grounded and passed through a $0.5-\mathrm{mm}$ sieve.

\subsection{Experimental Design and Statistical Analysis}

The experimental design for the study was a split-plot designed with two main plots (azide vs. non-azide) and four subplots (bare soil control, white on black agriplastic mulched soil, and plots solarized for 15 and 30 days). Each plot was replicated four times, resulting in a total of experimental 32 plots. Sodium azide was then applied to sixteen plots, while the remaining other sixteen plots were not treated with sodium azide.

The overall $\mathrm{F}$ test was run, using the General Linear Model of the SAS Software packages [17]. The differences between means among treatments were analyzed using Tukey's mean comparison test, and mean differences between the control and treated plots was determined using the Dunnett's tests. The level of significance was determined at the 0.05 level of significance.

\section{Results and Discussion}

\subsection{The Effects of Solarization and Sodium Azide on Selected Soil Parameters}

Soil $\mathrm{pH}$ observed in the treatment plots ranged from 5.7 to 7.1 (Table 1). Solarization and mulching resulted in a significant decrease in soil $\mathrm{pH}(\mathrm{p} \leq 0.05)$. Azide treated plots were found to have generally higher $\mathrm{pH}$ values compared to non-azide treated plots. Among the solarized plots, no significant differences in $\mathrm{pH}$ were observed between the azide and non-azide treated soils for both periods of solarization. However, a significant difference
Table 1. Effects of sodium azide and non sodium azide treatments on soil $\mathrm{pH}$ and organic carbon content.

\begin{tabular}{ccccc}
\hline & \multicolumn{2}{c}{$\mathrm{pH}$} & \multicolumn{2}{c}{$\%$ Org-Carbon } \\
\hline Azide Levels & $\mathrm{AZ}$ & $\mathrm{NAZ}$ & $\mathrm{AZ}$ & $\mathrm{NAZ}$ \\
$\mathrm{S}_{30}$ & $6.2^{\mathrm{b}}$ & $6.1^{\mathrm{b}}$ & $0.49^{\mathrm{c}}$ & $0.62^{\mathrm{abc}}$ \\
$\mathrm{S}_{15}$ & $6.3^{\mathrm{b}}$ & $6.2^{\mathrm{b}}$ & $0.57^{\mathrm{abc}}$ & $0.71^{\mathrm{a}}$ \\
Mulched Soil & $6.5^{\mathrm{b}}$ & $5.7^{\mathrm{c}}$ & $0.69^{\mathrm{ab}}$ & $0.52^{\mathrm{bc}}$ \\
Control Soil & $7.1^{\mathrm{a}}$ & $7.0^{\mathrm{a}}$ & $0.57^{\mathrm{abc}}$ & $0.57^{\mathrm{abc}}$ \\
\hline
\end{tabular}

AZ_Azide treated plots; NAZ - Non Azide treated plots; \%-Org-CPercent organic carbon; ${ }^{a, b, c, d}$ - means with the same letter are not signifIcantly different from each other at $(\mathrm{p} \leq 0.05)$ across and between rows and columns; $\mathrm{S}_{30}$-Solarization for 30 days, $\mathrm{S}_{15}$-Solarizationfor 15 days.

$(\mathrm{p} \leq 0.05)$ in $\mathrm{pH}$ was observed for the agrimulched plots.

\subsection{Effect of Solarization and Azide Amendment on Organic Carbon}

The highest amount of organic carbon was found in plots not amended with azide and solarized for 15 days, and the lowest was found in plots not amended and solarized for 30 days, which had azide amendment (Table 1). Soils solarized for 15 days resulted in a significant increase in soil organic carbon content, compared to the bare control soil, while agrimulching resulted in a significant decrease $(\mathrm{p} \leq 0.05)$. Soils solarized for 15 days and amended showed a significant decrease in carbon content compared to bare control soils, while agrimulching significantly increased soil organic matter content (Table 1). In agrimulched plots, however, azide amendment resulted in a higher percent organic carbon content, $0.69 \%$ in azide treated plots, compared to $0.52 \%$ without azide treatment (Table 1). The increase in organic matter content observed in the solarized plots could be attributed to slower mineralization. The reduction in both fungal and bacterial populations resulting from solarization may have led to a decrease in microbial activity, resulting in a lower conversion of organic carbon to carbon dioxide. Levels of organic carbon have been observed to increase following fumigation $[18,19]$. The significantly higher carbon content observed in the azide treated mulched plots may be due to a selective increase in microbial biomass due to a moderate influence of the mulch on azide.

\subsection{Effects of Solarization and Sodium Azide Amendment on Phosphomonoesterase Activity}

The test of the effects of solarization, mulching and azide treatment on acid phosphomonoestrase (ACP) activity showed a statistically significant difference between the subplots $(p \leq 0.05)$. Solarization for 30 days and mulching resulted in significantly higher ACP activity, 187 and 
$236 \mu \mathrm{g}$ p-nitrophenol g${ }^{-1}$ soil hr ${ }^{-1}$ respectively, compared to the control soil (Figure 1). Solarization for 15 days, however, resulted in a lower ACP activity. With the exception of plots that were solarized for 15 days, addition of sodium azide as an amendment resulted in a significant lowering of ACP activity. Mulching was found to significantly reduce the effect of azide application compared to solarization. Combined application of azide with solarization resulted in significant reduction of all the soil enzymes studied.

Statistically significant differences $(p \leq 0.05)$ were also observed among the subplots for alkaline phosphomonoestrase (ALKP) activity (Figure 2). Alkaline phosphatase activity found in the solarized and mulched plots were all lower than that found in the bare soil. Among the solarized plots, solarization for 15 days significantly decreased the alkaline phosphatase activity. In almost all the plots, addition of azide as amendment resulted in

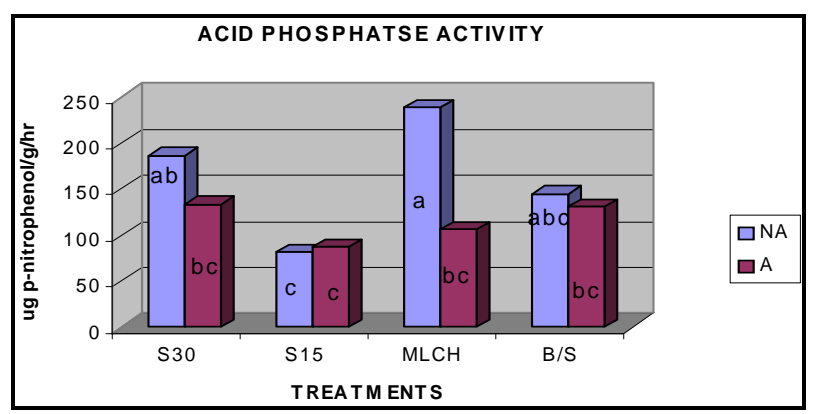

Figure 1. Comparison of activities acid phosphomonoesterases activity in azide versus non-azide treated soils (a, b, c, d-means with the same letter are not significantly different from each other at $(p \leq 0.05) ; A$-azide treated plots; NA-non azide treated plots; $S_{30}$ - solarization for "30" days, $S_{15}$ - solarization for 15 days, MLCH-mulched soil, $\mathbf{B} / \mathbf{S}$-bare soil control).

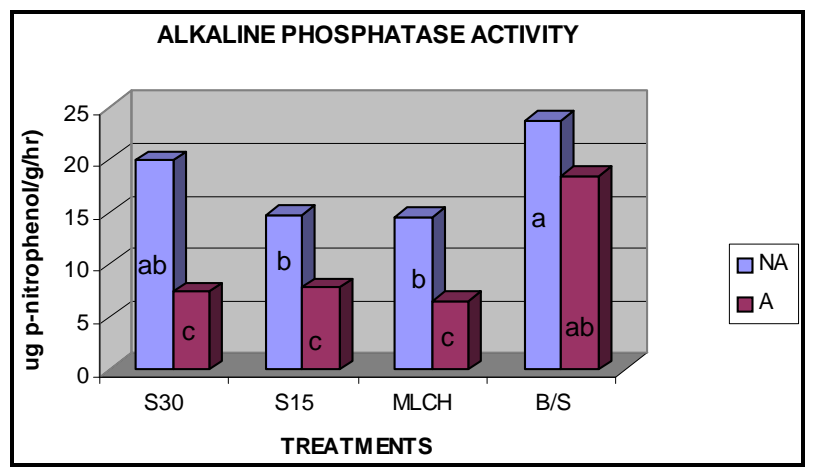

Figure 2. Comparison of alkaline phospho-monoesterases activity in azide versus non-azide treated soils $(a, b, c, d-$ means with the same letter are not significantly different from each other at $(p \leq 0.05)$; $\mathrm{A}-$ azide treated plots; NAnon azide treated plots; $\mathrm{S30}$ - solarization for "30" days, S15 - solarization for 15 days, MLCH-mulched soil, B/Sbare soil control). decrease of both phosphomonoesterases activities (Figures 1 and 2). However, solarization and mulching produced different responses to either ACP or ALKP activities. Alkaline phosphatase activities in both solarized and mulched soils were significantly lower than the control soils, which received no treatments. Mulching and solarization of soil for 30 days without azide treatment resulted in increased ACP activity.

The reason for the differences between the ACP and ALKP activities may be due to the $\mathrm{pH}$ ranges in which both enzymes are active and also due to the influence of the treatments on both $\mathrm{pH}$ and organic matter content. For example, mulching significantly reduced the $\mathrm{pH}$ of the mulched soils compared to the control or bare soils 5.7 compared to 7.0 (Table 1). This reduction in soil $\mathrm{pH}$ might have accounted for the higher values in the ACP activity observed, since the acid phosphatases have their optimum $\mathrm{pH}$ in the acidic $\mathrm{pH}$ range.

\subsection{Effect of Solarization and Sodium Azide on Phosphodiesterase and Arylsulfatase Activities}

Both solarization of soil for 30 days and mulching, with and without azide treatment had the effects of significantly $(\mathrm{p} \leq 0.05)$ lowering phosphodiesterase activity. However, unlike ALKP, the lowering of activity in the plots solarized for 15 days was significantly less (Figure 3). With the exception of the mulched soils, azide application resulted in a significant reduction in the phosphodiesterase activity (Figure 3). Organic matter and $\mathrm{pH}$ of the mulched plots increased when sodium azide amendment was applied (Table 1). This may indicate that the increase observed in the sodium azide treated mulched soils may be related to the $\mathrm{pH}$ and organic carbon content.

The effects of treatments on arylsulfatase activity was very similar to that observed for phosphodiesterase activity (Figure 4) in that solarization and mulching tended to significantly decrease the enzyme activities in relation to the control/bare soil. For example, azide treatment resulted in a significant reduction in arylsulfatase activity in all plots, except for those that were mulched. This may suggest that both of these enzymes may be responding to very similar effects produced by solarization and mulching. It can also be concluded from these observations that, while azide treatment generally reduced the activity of these enzymes, mulching may not significantly reduced its effects.

\subsection{Effects of Solarization and Azide Applications on Soil Microbial Populations}

Both solarization and mulching resulted in a significant reduction in "total" fungal population as enumerated by 


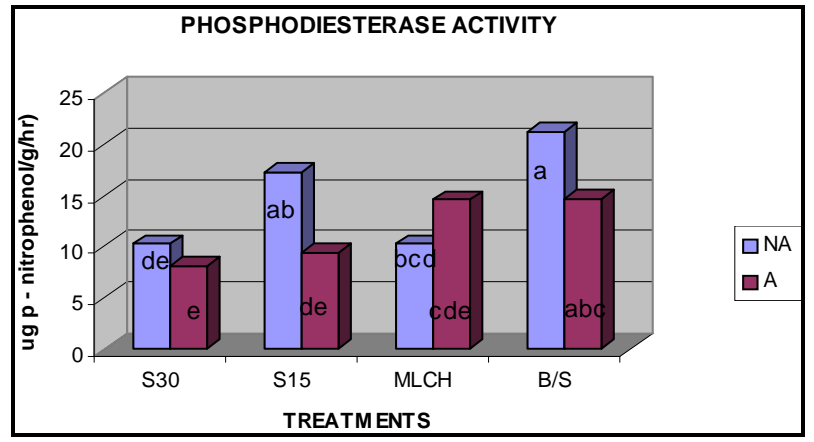

Figure 3. Comparison of phosphodiesterase activity in azide versus non azide treated soils (A-azide treated plots; NAnon azide treated plots; $a, b, c, d, e-$ means with the same letter are not significantly different from each other at ( $\mathrm{p} \leq$ $0.05)$; S30, S15-solarization for " 30 " and " 15 " days respectively, MLCH-mulched soil, B/S-bare soil control).

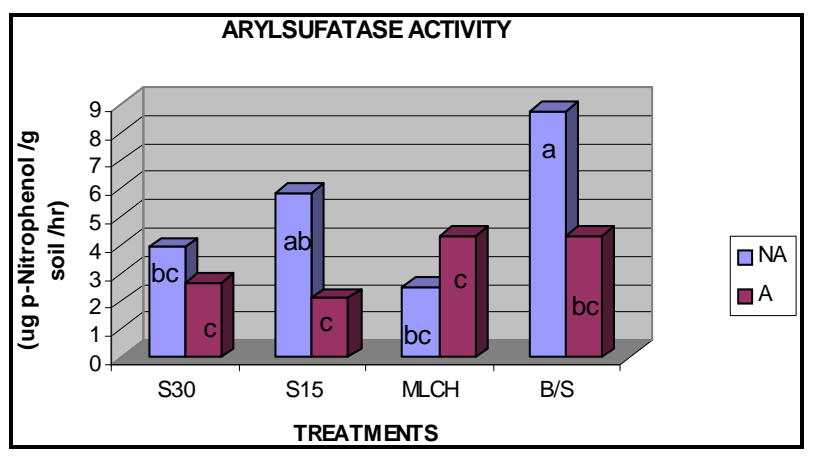

Figure 4. Comparison of soil arylsulfatase activity in azide versus non azide treated soils $(a, b, c, d-$ means with the same letter are not significantly different from each other at ( $\leq$ 0.05); A-azide treated plots; NA-non azide treated plots; S30, S15-solarization for "30" and "15" days respectively, MLCH-mulched soil, B/S-bare soil control).

Table 2 .Comparison of microbial populations in the soils treated with or without sodium azide treatments.

\begin{tabular}{ccccc}
\hline & \multicolumn{2}{c}{ "Total” Fungi } & \multicolumn{2}{c}{ "Total” Bacteria } \\
\hline & cfu $\left(\times 10^{2}\right) \mathrm{g}^{-1}$ dry soil_ & \multicolumn{2}{c}{ cfu $\left(\times 10^{4}\right) \mathrm{g}^{-1}$ dry soil_ } \\
\hline Treatment & $\mathrm{AZ}$ & $\mathrm{NAZ}$ & $\mathrm{AZ}$ & $\mathrm{NAZ}$ \\
\hline $\mathrm{S}_{30}$ & $57.8^{\mathrm{d}}$ & $124^{\mathrm{bc}}$ & $53.7^{\mathrm{c}}$ & $122.3^{\mathrm{a}}$ \\
$\mathrm{S}_{15}$ & $82.0^{\text {cd }}$ & $98.4^{\mathrm{bcd}}$ & $40.1^{\mathrm{c}}$ & $93.9^{\mathrm{ab}}$ \\
$\mathrm{MLCH}$ & $65.6^{\text {cd }}$ & $154.8^{\mathrm{ab}}$ & $100.1^{\mathrm{a}}$ & $92.0^{\mathrm{ab}}$ \\
$\mathrm{B} / \mathrm{S}$ & $60.9^{\text {cd }}$ & $196.1^{\mathrm{a}}$ & $60.3^{\mathrm{bc}}$ & $100.6^{\mathrm{a}}$ \\
\hline
\end{tabular}

AZ-Azide treated plots; NAZ-Non Azide treated plots; ${ }^{a, b, c, d}$ - means with the same letter are not significantly different from each other at $(\mathrm{p} \leq$ 0.05 ) across and between rows and columns; $\mathrm{S}_{15}, \mathrm{~S}_{30}-$ Solarization for 15 and 30 days respectively, MLCH—Mulched soil, B/S-Bare soil Control.

plate counts (Table 2). The reduction in fungal populations in the soil was more pronounced in the solarized soils than in the mulched soils. This observation is consistent with the fact that much higher temperatures are produced in the solarized than the mulched soils and such temperatures are high enough to kill the majority of mesophilic microorganisms. As has been observed with enzyme activities, azide treatment resulted also in a significant reduction in fungal populations when compared with the non-azide treated soils (Table 2). The "total" fungal populations observed in azide treated control soils, mulched and solarized for 15 days were all found to be significantly higher than those observed for soils solarized for 30 days (Table 2). No significant differences ( $p$ $\leq 0.05$ ) were observed between the "total" fungal populations in the azide treated plots for the control soils, mulched, and plots solarized for 15 days. "Total" bacterial populations in soils solarized for 30 days were not significantly different from the control plots but were and plots that were solarized for 15 days.

In contrast to the fungal population, bacterial populations in plots solarized for 30 days were lower than those found in the mulched plots (Table 2). These observations suggest that the effects of solarization and mulching on soil microbial populations may not be even among the major microbial groups found to be significantly affected by solarization. Azide treatment resulted in a significant reduction in "total" bacteria population in all plots, except for the mulched plots compared to their respective non-azide treated counterparts. In the mulched soils, addition of azide resulted in higher bacterial population as compared to the respective non-azide treated plot (Table 2). This observation is similar to that found in the response of the mulched soil to $\mathrm{pH}$, organic carbon content, arylsulfatase and phosphodiesterase activities. The response of bacteria and enzyme activity to azide application in mulched plots may be related to the soil $\mathrm{pH}$ and organic matter content.

\subsection{Comparison of Enzyme Activities of Bare Soil and Solarized, Mulched and Azide Treated Soils.}

Effects of solarization, mulching and sodium azide application on soil enzyme activity were evaluated by comparing the control bare plot to the treated plots (Table 3). In general, solarization, mulching, and azide treatment resulted in reduction in the enzyme activity, when compared to the bare plot control. Significant reductions in arylsulfatase activity resulted from all the treatments. Plots that received sodium azide treatment generally had the highest reduction in arylsulfatase activity. Soils that were solarized for 15 days had the lowest significant decrease in arylsulfatase activity when compared to the control soil. Phosphodiesterase and alkaline phosphatase activities showed similar responses when compared with the control bare soils (Table 3). With the exception of the azide-treated bare soils and soils that 
Table 3. Difference between means of the control soil (BS) and other treatments for soil enzyme activities.

\begin{tabular}{ccccc}
\hline TRT-COMP & ACP & ALKP & ARYLS & PDE \\
\hline BS-(BS + AZ) & -17.3 & -5.3 & $-4.1^{* *}$ & -4.8 \\
BS-(S $30+$ AZ) & -10.9 & $-16.3^{* * *}$ & $-6.1^{* *}$ & $-13.2^{* *}$ \\
BS-(S15 + AZ & -56.6 & $-16.0^{* *}$ & $-6.6^{* *}$ & $-11.8^{* *}$ \\
BS-(MLCH + AZ) & -38.3 & $-17.3^{* *}$ & $-6.2^{* *}$ & $-10.9^{* *}$ \\
BS-MLCH & $94.3^{* *}$ & $-9.2^{* *}$ & $-4.4^{* *}$ & $-6.6^{* *}$ \\
BS-S & 42.1 & $-4.9^{* *}$ & $-4.8^{* *}$ & $-11.6^{* *}$ \\
BS-S $_{15}$ & -62.7 & -9.0 & $-2.9^{* *}$ & -4.0 \\
\hline
\end{tabular}

Comparisons with significant difference at the 0.05 and 0.01 levels are indicated by ${ }^{* *}$ and ${ }^{* * *}$ respectively across and between rows and columns; ACP - Acid phosphatase; ALKP-Alkaline Phosphatase, ARYLS-Arylsulfatase; PDE-Phosphodiesterase; MCLH-Mulched soil; BS-Bare Soil Control, $\mathrm{S}_{15}$-Solarization for 15 days; $\mathrm{S}_{30}$-Solarization for 30 days.

were solarized for 15 days, all treatments showed significant reductions in the respective enzyme activity.

The greatest reductions in activity for both enzymes when compared to the control soils were observed when azide was added to either mulched or solarized soils. This shows that the combination of solarization and mulching with azide affected these enzymes more than when azide was applied alone or when soils were either solarized or mulched. All the treatments resulted in the lowering of ACP activities when compared with the control, except for mulched soils and bare soils, which were solarized for 30 days. They showed increase in levels of ACP activity when compared with the control bare soils (Table 3). All the differences observed for ACP were not significant, except for the mulched soils that showed a significant increase $(p>0.05)$ in activity compared to the control bare soil.

\subsection{Comparison of Soil pH and Microbial Popu- lations of Control (Bare Soil) with Solarized, Mulched and Azide Treated Soils}

Azide-treated control soils and mulched soils were the only treatments which resulted in significant differences in soil $\mathrm{pH}$ when compared to the control (Table 4). Addition of azide to the bare soils resulted in a significant increase in the soil $\mathrm{pH}$, while in the case of the mulched soils, azide treatment resulted in significant decreases in the soil $\mathrm{pH}$ compared to the control. No significant differences were also found between the control and the treated soils with respect to organic carbon content. Except for the mulched soils, which did not receive azide treatment, "total" fungal populations were significantly reduced by solarization and addition of azide.

As with the enzyme activities, the largest reductions were seen in soils, which received azide treatment. In contrast to total fungal populations, "total" bacteria populations were significantly reduced in only three of
Table 4. Difference between means of the control soil (BS) and other treatments for $\mathrm{pH}$ and microbial populations.

\begin{tabular}{cccc}
\hline $\begin{array}{c}\text { Component } \\
\text { Treatment }\end{array}$ & $\mathbf{p H}$ & Total Bacteria & Total Fungi \\
\hline BS-(BS + AZ) & $0.57^{* *}$ & $-135.13^{* *}$ & $-40.31^{* *}$ \\
BS-( $\left.\mathrm{S}_{30}+\mathrm{AZ}\right)$ & --0.01 & $-138.25^{* *}$ & $-46.94^{* *}$ \\
$\mathrm{BS}^{*}\left(\mathrm{~S}_{15}+\mathrm{AZ}\right)$ & 0.17 & $-114.06^{* *}$ & $-60.50^{* *}$ \\
$\mathrm{BS}-(\mathrm{MLCH}+\mathrm{AZ})$ & $-0.46^{* *}$ & $-130.44^{* *}$ & 0.56 \\
$\mathrm{BS}-\mathrm{MLCH}$ & 0.37 & -41.31 & -8.63 \\
$\mathrm{BS}^{*} \mathrm{~S}_{30}$ & -0.17 & -72.06 & 21.69 \\
$\mathrm{BS}_{\mathrm{S}}$ & 0.30 & -97.63 & -6.69 \\
\hline
\end{tabular}

Comparisons with significant difference at the 0.05 levels is indicated by ${ }^{*}$ across and between rows and columns (BS-Bare Soil, $\mathrm{S}_{15}$ - Solarization for 15 days; $\mathrm{S}_{30}-$ Solarization for 30 days. AZ-Azide, MLCH-Mulched soil).

the treatments when compared with the control. As has been observed for the other parameters measured, the largest significant reductions were observed for the azide-treated soils. For bacteria and fungi populations, solarization for 30 days, combined with azide application, resulted in the largest significant reduction in population.

\section{Conclusion}

The main objective of this study was to determine the effects of the length of solarization and sodium azide applications on some selected soil enzyme activities, chemical parameters, and on microbial populations. These factors were used because they have been proposed as possible indicators of soil quality. They have also been used for predicting and understanding the effects of agricultural and environmental perturbations on ecosystem sustainability. The outcome of this study suggested that solarization and application of sodium azide significantly reduced soil enzyme activity and microbial populations. However, the impact of azide and solarization on enzyme activities were not the same and were modified by mulching or how long soils were solarized. Thus, a further understanding of mechanisms involved is needed to fully understand their long-term effects on soil sustainability and also to find which enzyme can best predict negative impacts.

\section{Acknowledgements}

Funding for this research was provided by the following sources: Tuskegee University George Washington Carver Agricultural Experiment Station and the United States Department of Agriculture National Institute of Food and Agriculture (NIFA).

\section{REFERENCES}

[1] S. C. Wofsy, M. B. McElroy and Y. L. Yung, "The 
Chemistry of Atmospheric Bromine," Geophysical Research Letters, Vol. 2, No. 6, 1975, pp. 215-218.

[2] M. J. Prather, M. B. McElroy and S. C. Wofsy, "Reductions in Ozone at High Concentrations of Stratospheric Halogens," Nature, Vol. 312, No. 5991, 1984, pp. 227231. doi: $10.1038 / 312227 \mathrm{a} 0$

[3] S. Wilhelm, R. C. Storkan and J. E. Sagen, "Verticillium wilt of Strawberry Controlled by Fumigation of Soil with Chloropicrin and Chloropicrin-Methyl Bromide Mixtures," Phytopathology, Vol. 51, 1961, pp. 744-748.

[4] J. J. Stapleton and J. E. DeVay, "Soil Solarization a NonChemical Approach for Management of Plant Pathogens and Pests," Crop Protection, Vol. 5, No. 3, 1986, pp. 190198. doi:10.1016/0261-2194(86)90101-8

[5] J. Katan, A. Greenberger, H. Alon and A. Grinstein, "Soil Solarization for Plant and Weed Control," Proceedings of the 16th Congress of Mediterranean Phytopathological Union, Vol. 84, 1984, pp. 115-117.

[6] C. Stevens, V.A. Khan, J. E. Brown, G. J. Hochmuth, W. E. Splittstoesser and D. M. Granberry, "Plastic Chemistry and Technology as Related to Plastic Culture in Solar Heating," Chapter 10, 1991, pp. 141-158.

[7] J. J. Stapleton and J. E. DeVay, "Soil Solarization: A Natural Mechanism of Integrated Pest Management," In: R. Reuveni, Ed., Novel Approaches to Integrated Pest Management, Lewis Publishers, Boca Raton, 1995, pp. 309-322.

[8] R. Rodriguez-Kabana and J. R. Ackridge, "Sodium Azide [SEP-100] for the Control of Nematodes and Weed Problems in Green Pepper Production," Proceedings of the Annual International Research Conference on Methyl Bromide Alternatives and Emissions Reductions, San Diego, 3-6 November 2003, p. 46.

[9] J. Katan, A. Greenberger, H. Alon and A. Grinstein, "Solar Heating by Polyethylene Mulching for the Control of Diseases Caused by Soil Borne Pathogens," Phytopathology, Vol. 66, No. 5, 1976, pp. 683-688. doi:10.1094/Phyto-66-683
[10] M. A. Tabatabai and J. M. Bremner, "Use of p-Nitrophenyl Phosphate for Assay of Soil Phosphatase Activity," Soil Biology \& Biochemistry, Vol. 1, No. 4, 1969, pp. 301-307. doi:10.1016/0038-0717(69)90012-1

[11] M. G. Browman and M. A. Tabatabai, "Phosphodiesterase Activity of Soils," Soil Science Society of America Journal, Vol. 42, No. 2, 1978, pp. 284-290. doi:10.2136/sssaj1978.03615995004200020016x

[12] M. A. Tabatabai and J. M. Bremner, "Factors Affecting Soil Arylsulphatase Activity," Soil Science Society of America Journal, Vol. 34, No. 3, 1970, pp. 427-429. doi:10.2136/sssaj1970.03615995003400030023x

[13] E. A. Curl and R. Rodriguez-Kabana, "Herbicide-Plant Diseases Relationship," In: E. D. Camper, Ed., Research Methods in Weed Science, 2nd Edition, Southern Weed Science Society, Las Cruces, 1986, pp. 429 - 455.

[14] A. Walkley and C. A. Black, "A critical Examination of a Rapid Method of Determining Organic Carbon in Soils: Effects of Variations in Digestion Conditions and of Inorganic Constituents," Soil Science, Vol. 63, No. 4, 1947, pp. 251-263. doi:10.1097/00010694-194704000-00001

[15] M. L. Peech, "Methods of Soil Analyses for Soil Fertility Investigations," United States Department of Agriculture, Washington DC, 1947, p. 25.

[16] T. Greweling and M. L. Peech, "Chemical Soil Test," Agriculture Experiment Station, Cornell University, 1960, Ithaca, p. 960.

[17] Statistical Analysis Software, SAS, Cary, 2000.

[18] D. S. Jenkinson, and D. S. Powlson, "The Effect of Biocidal Treatments on Metabolism in Soil. I. Fumigation with Chloroform," Soil Biology \& Biochemistry, Vol. 8, No. 3, 1976, pp. 167-177. doi:10.1016/0038-0717(76)90001-8

[19] M. Gennari, M. Negre and R. R. Ambrosoli, "Effects of Ethylene Oxide on Soil Microbial Content and Some Soil Chemical Characteristics," Plant and Soil, Vol. 102, No. 2, 1987, pp. 197-200. 